\title{
The Impact of ERP System's Usability on Enterprise Resource Planning Project Implementation Success via the Mediating Role of User Satisfaction
}

\author{
Eman Yassien \& Raja'a Masa'deh \\ Department of Information Technology \\ World Islamic Science and Education University, Jordan \\ E-mail: Eman.yassien@gmail.com \\ Monira Mufleh \\ Department of Management Department \\ World Islamic Science and Education University, Jordan
}

\author{
Ala'aldin Alrowwad \\ Departments of Management \\ The University of Jordan, Aqaba, Jordan \\ Ra'ed Masa'deh \\ Departments of Management Information Systems \\ The University of Jordan, Jordan
}

Received: Jan. 6, 2017 Accepted: June 27, $2017 \quad$ Published: July 1, 2017

doi:10.5296/jmr.v9i3.11186 URL: https://doi.org/10.5296/jmr.v9i3.11186

\begin{abstract}
Organizations in the current environment need to create and sustain their competitive advantages. ERP (Enterprise Resource Planning) solutions are considered a strong tool that
\end{abstract}




\section{Macrothink}

helps organizations to succeed and arise. But ERP projects' implementation has relatively low success rates in which it may affect and shake the whole organizational performance. This study searches the power of software usability to achieve ERP Project Implementation Success (ERP-PIS) considering the mediating role of user information satisfaction (UIS). A set of research's hypotheses have been constructed. This study adapts a positivism view, using the survey strategy. The questionnaires were filled by 106 managers who use ERP systems or affected by ERP systems in different organizations. The findings of the research ensure the fitness of the model, and that mediation role of user information satisfaction (UIS) in Jordan is highly visible. Also, the research shows up the strong power of usability to achieve ERP-PIS. Based on the findings, development of ERP applications would be improved by software organizations in terms of usability, and organizations need to acquire ERP applications would also improve their decisions in choosing an ERP solution.

Keywords: Usability, Enterprise Resource Planning, ERP, User Satisfaction, Information, Project Implementation Success. 


\section{Introduction}

Several researchers consider the information systems and in particular the information technology (IT) and its flexibility as an enabler to achieve the desired competitive advantages, and as a crucial support to operational and strategic business decisions (Al Azmi et al., 2012; Alkalha, et al., 2012; Altamony et al., 2012; Masa'deh, 2012, 2013; Masa'deh \& Shannak, 2012; Shannak, et al., 2010; Vratskikh, et al., 2016); thus a detailed research is required to examine the role of such IT applications in enhancing the managerial decisions. In addition, scholars (e.g. Alshurideh, et al., 2012; Hajir, et al., 2015; Kannan \& Gharaibeh, 2013; Maqableh et al., 2014; Masa'deh \& Shannak, 2012; Masa'deh, et al. 2015; Masa'deh, et al. 2017; Obeidat, et al., 2012) emphasize the need for large firms to integrate their IT systems such as ERP systems with their knowledge management strategies and processes in order to survive in their highly competitive business environments, which in turn could accelerate the managerial decisions as well.

Statista's researches show that ERP Software market has an increasing value, it was obtained to be 82.1 billion $\$$ in 2015 with (SAP) having the largest market share (Statistia, 2017). It also shows rising revenue for global Enterprise applications. The increasing value of the ERP software market indicates an increasing demand for Enterprise systems. Beyond than that ERP systems reshaped business environment and helped to transform the competition into higher levels; ERP systems are also becoming necessities to meet the needs of the growing market in such a dynamic environment to help creating and sustaining a competitive advantage (Yassien, 2015; Yassien et al., 2016).

Unfortunately, with this huge demand, studies show that $37 \%$ of global organizations do consider their experience in adopting ERP projects to be unsuccessful (Sharma et al, 2016). Davenport (2000) even describes the process of implementing ERP as a critical mission. Lots of challenges cause this mission to be critical either technological or non-technological. A wide range of studies searched the non-technological challenges such as organizational factors, implementation costs and others (Wang et al, 2016; Almajali et al, 2016). But little attention was given to mix of technological and non- technological challenges. This paper studies the impact of ERP software usability factor (Technological) on ERP project implementation success, considering the mediating role of user satisfaction (Non-Technological). Moreover, Systems' usability is becoming an issue, and considered a success factor. For example, the European Parliament and the Council of the European community's has initiated a directive that forces employers to adapt usability in software development (Tretten \& Karim, 2014).

This research is applied and carried out for descriptive and explanatory purposes. The quantitative approach is used, thus a survey is a typical strategy for collecting information from the respondents. The following section recites the most effective work in literature in this regard. Section 3 describes the research model and methodology, section 4 discusses the practical findings and section 5 provides the conclusion. 


\section{Literature Review}

\subsection{Software Usability}

Some studies show that software projects should spend at least $10 \%$ of their budget on usability, in order to increase their effectiveness by $100 \%$ (Nielsen \& Gilutz, 2016). Usability feature is a very critical factor that affects success of software; it's studied as the most effective factor in Human Computer Interaction (HCI) knowledge area (Juristo et al, 2007) and it's also defined as an important quality attribute by ISO/IEC 9126 (Bevan et al, 2016). Usability, also highly affects the project's acceptance by the end user, thus affects the whole project's success or failure (Mahanti \& Evan, 2012). Bias \& Mayhew (2005) mentioned that usability impacts productivity positively and decreases user support, training cost, and overall cost. The emerging and changing environment is reflected highly on the usability requirements needed for software in order to reach its objectives. Hellman \& Rönkkö (2008) and Hassenzahl et al. (2010) regard usability as being a "hygiene factor"; usability is part of the default system concepts. Till now, a unified definition for usability is not agreed upon. However, usability in dictionary is defined as "capability of being used" (Bevan et al, 2015). Accordingly, ISO 9241-11 (Bevan et al, 2015) defined usability as "the extent to which a product can be used by specified users to achieve specified goals with effectiveness, efficiency and satisfaction in a specified context of use". Although the new version of ISO standards keeps same definition for usability, but the standards were revised to reflect the development of usability perspective (Bevan et al, 2016).

Factors of usability that were introduced in literature agreed mostly to consider usability as the sum of efficiency, effectiveness, learnability and user satisfaction (Aykin, 2016; Bevan et al, 2016; Dubey et al, 2012; Dix et al, 1998; Iqbal et al, 2016; Loureiro et al, 2015; Masa'deh et al., 2016; Nielsen \& Landauer, 1993; Nielsen \& Loranger, 2006; Usability, 2017). Other studies added more factors such as security (Abran et al, 2003) flexibility (Shackel, 1991), universality (Seffah et al, 2006) and others. Gupta et al (2014) introduced a comprehensive definition for usability that includes seven main attributes: efficiency, productivity, effectiveness, memorability, safety, universality and satisfaction. Authors of this study adopt Gupta et al (2014) factors for usability with some updates. So, main factors to be studied for usability in this study are: efficiency, effectiveness, memorability, security, and universality. Whereas, efficiency is defined as the ability of the ERP system to enable users to produce the desired results, considering the amount of used resources (Bevan et al, 2016; Gupta et al, 2014). Effectiveness, measures the ability of ERP system to accomplish specific tasks producing desired result correctly and precisely (Bevan et al, 2016; Gupta et al, 2014). Memorability, checks if ERP systems' are understandable and clear (Gupta et al, 2014). Security, measures the ability of ERP system to avoid security problems related to their environment. Finally Universality measures the ability of ERP system to be used by diverse types of people from different culture backgrounds with software product and practical utility of software product. ISO 9241-11 defined efficiency previously as the ratio of effectiveness divided by the resources consumed (Bevan et al, 2016), which measures productivity for continuous output, so the authors consider that productivity is part of effectiveness, and not an independent sub-factor. 


\subsection{User Satisfaction}

General concept for user satisfaction has been a fundamental research topic shared by several knowledge areas due to its benefits (Choi \& Moon, 2017; Finley et al, 2017; Maqableh \& Karajeh, 2014; Masa'deh \& Gharaibeh, 2015; Wang \& Song, 2017; Zainal et al, 2013). User satisfaction is important to manage customer relationship, to gain and to maintain their loyalties. Also, it has been an important component of business strategy to reach the competitive environment (Gitman \& McDaniel, 2007). It also affects highly improvement of products (Parasuraman, 1988) and increases productivity (Halkos \& Bousinakis, 2010). But unfortunately User's impression on a software product's quality in general has limited number of literature reviews especially on how to measure it (Atoum \& Bong, 2013, 2015). User information satisfaction (UIS) has been studied specifically in the field of Information Systems (IS) and it has been considered as an important factor of IS success (Au et al, 2008; Bharati \& Chaudhury, 2006; DeLone \& McLean, 2003; Finley et al, 2017; Sugianto \& Tojib, 2015).

UIS initiated to measure data processing effectiveness (Ives et al., 1983). Newer concept of UIS presented by Doll \& Torkzadeh (1988); where they added the concept of end-user satisfaction as user's attitude towards the used system. Sprenget al. (1996) consider user satisfaction as an evaluation of the IS user experience. Ives et al (1983) defined UIS as in terms of meeting the IS users' requirements. Sprenget al. (1996) defined it as evaluation of the entire user's experience. ISO 9241-11 (Bevan et al, 2016) sets the fundamental for user satisfaction by describing UIS as positive attitudes of the user towards the use of the product and feeling of comfortable. The new release of ISO identifies UIS as: "The extent to which attitudes related to the use of a system, product or service and the emotional and physiological effects arising from use are positive or negative" (Bevan et al, 2016). For this research UIS is measured via responses, feelings of user during ERP software usage. Gable et al (2008) shifted user satisfaction used by D\&M model from being as a measure to be a dimension, thus in this research UIS is removed from usability sub-factor, and treated as a mediator. According to Sekaran \& Bougie (2013) mediator is developed due to causal effect and it explains the influence of the independent variable (Usability) on the dependent variable (ERP Implementation Project Success- ERP-IPS).

\subsection{ERP System}

Material Resource Planning (MRP) systems blazed the trail for the new ERP system. MRP was developed to solve the universal manufacturing equation and to determine future requirements according to master schedule, bill of material and inventory records (Leon, 2014). MRP was expanded to include operational production and financial planning with some simulation capabilities and introduced as MRP II or (Manufacture Resource Planning System) (Leon, 2014). Later it was obtained that potential advantages would be achieved by integrating MRP II to both customers and suppliers functions with decision making abilities, which causes better focus on value added activities (Leon, 2014).That gave rise to ERP Solutions; ERP solutions automate and integrate all management areas even human resource functions and design functions (Obeidat et al., 2013; Sadrzadehrafiei et al, 2013; Leon, 2014). 
ERP provides lots of monetary and non-monetary benefits (Sadrzadehrafiei et al, 2013; Leon, 2014; Tarhini et al, 2015) as follows.

Some authors such as Tasevska et al. (2014) Presents a positive impact for ERP systems on organizational success in terms of client satisfaction, customer service and quality measures. Other benefits that relates to reduction of inventory, increased productivity are introduced by Davenport (2000), Shen et al. (2016), Markus et al. (2000), Wittstruck \& Teuteberg (2012) and others. Improvement of financial cycles and cost reduction were also cited in literature (Leon, 2014). More effective business and supply chain management processes, improved communications, better integration between different functions are other benefits recorded by (Al Mashari et al, 2003, Kateb et al., 2015; Umble et al, 2003; Wittstruck \& Teuteberg, 2012). Also, Shen et al (2016) recorded an increased profit and better performance level caused by ERP system usage.

On the other hand, ERP is not being only a software, and it's considered a whole solution that causes dramatic change in organizational processes and management, and sometimes leads to a total process reengineering; thus the promising benefits are full of dangers that may lead organizations to serious consequences such as bankruptcy in some cases (Abu Shanab et al, 2015). For example, Wu et al. (2008) recounts how Dell lost after two years of building its ERP system, which reached to lose about \$M200. Also, a study shows that $40 \%$ of all ERP implementations achieve only partial implementation and about $20 \%$ are considered as total failures (Koh et al, 2009). The implementation is considered a socio-technical challenge. (Shah et al, 2011; Wang et al, 2016) Some compromise is needed between organizational flow of work and ERP systems in order to reach maximum benefits and avoid potential risks. That's why the process of implementation was heavily studied in literature to investigate ERP implementation process as discussed in the next section (Leon, 2014; Wang et al, 2016).

\subsection{ERP Project Implementation Success (ERP-PIS)}

Looking at literature review, the researcher finds two main streams; one of them handles the determinants of success and failure such as critical success factors (Sammon \& Adam, 2010; Yen \& Sheu; Umble et al., 2013), while the other, works on ERP project success measures (Almajali et al, 2016; Abu Shanab, 2014, Hong et al, 2016). Although it is very important to study critical success/failure factors, but first, it is out of the scope of this research. Second, identifying good success criteria is considered as a perquisite for specifying critical success factors. Unfortunately, the second stream was poorly studied.

Many researchers use IS success models to measure ERP projects implementation success, such as D\&M Model (Hong et al, 2016; Veiga, 2014; Sykes, 2015) and Gable et al model (2008). Gable, et al model (2008) has four factors determine IS success. First two factors (individual impact, and organizational impact) measure success at present time (snapshot of the organization's experience of the enterprise system at a point in time), while other two (information quality, system quality) measure the IS success on long term. D\& M Model measures IS success through net impact is defined as "the extent to which IS helps to reach success of individuals, groups, organizations, industries, and nations" DeLone \& McLean (2016). D \&M model proved its value in measuring IS success (Lone \& McLean, 2016). The 


\section{Macrothink

model is cited by more than 8,000 article still 2017. DeLone \& McLean (2016) emphasized that D\&M Model highly depends on the organizational context, and the selection of the particular success dimensions and depends on the nature and purpose of the system; So, the current research adapts both Gable and D\&M model to measure the ERP-PIS factor with some updates to commensurate with the ERP environment and the research's circumstances. Regarding this research, ERP success is determined by measuring impact of ERP usage on both Individuals and organization. ERP impact on individuals is determined through how much the ERP system impacted the employees regarding their performance as individuals and teams, their learning, their productivity, and their effectiveness in decision-making (Sedera et al, 2004; DeLone \& McLean, 2016; Gable et al, 2008). The organizational impact is a dimension that measures the effect of information on the organizational performance, organizational costs, cost reduction, overall productivity, value-added system, and changes to business processes (Sedera et al, 2004; DeLone \& McLean, 2016; Gable et al, 2008).

\section{Research Model and Hypotheses Formulation}

By using the above recited studies in section 2.0, the authors identified main components of the model, where usability is considered the independent variable, UIS represents the mediator and ERP-PIS are the dependent variable as shown in figure 1. The relation between the components was also constructed as usability. Accordingly, the main question of the research is formulated as follows:

What is the possible impact of usability on ERP projects implementation success (ERP-PIS) considering the mediating role of usability in Jordan? 


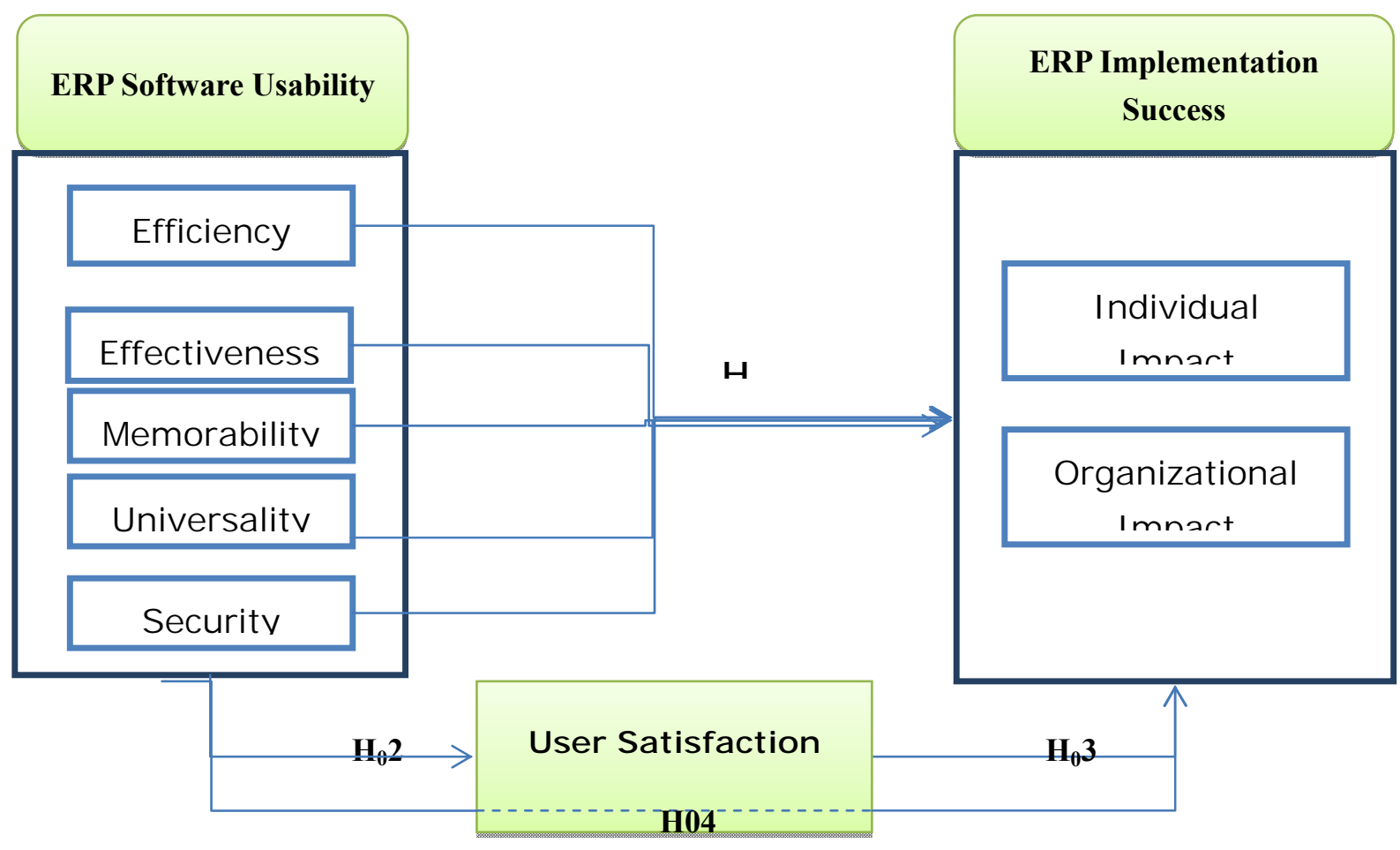

Figure 1. The Proposed Model

\subsection{Research Hypotheses}

To answer the question above mentioned, the researchers derived the following main hypotheses:

$\mathbf{H}_{\mathbf{0}}$ 1: There is no significant impact at level $(P \leq 0.05)$ of Usability on ERP projects implementation success (ERP-PIS).

$\mathbf{H}_{0}$ 2: There is no significant impact at level $(\mathrm{P} \leq .05)$ of Usability on (User Information Satisfaction (UIS).

$\mathbf{H}_{0}$ 3: There is no significant impact at level $(\mathrm{P} \leq .05)$ of User Information Satisfaction (UIS) on ERP projects implementation success (ERP-PIS).

$\mathbf{H}_{\mathbf{0}}$ 4: There is no significant impact of User Information Satisfaction (UIS) to explain the impact of Usability on ERP projects implementation success (ERP-PIS).

\section{Research Methodology}

This research is applied and carried out for descriptive and explanatory purposes. The quantitative approach is used, thus a survey is a typical strategy for collecting information from the respondents. The statistical analysis is undertaken in this research using the Structural Equation Modeling (SEM) approach with Partial Least Square (PLS).

This paper builds its work upon both secondary and primary sources of data (Al-Najjar et al., 
2013, 57; Sekaran \& Bougie, 2013, 113). Secondary data is presented in section 2 of this research (Sekaran \& Bougie, 2013, 113), while primary data is being obtained through survey using a questionnaire, whereas questionnaires are used usually in statistical analysis to explain the relationship between variables (Sekaran \& Bougie, 2013, 148). The questionnaires were filled by 106 managers who use ERP solution in Jordan. The random sample has been chosen because it allows the researcher to select the sample without bias. The sample selected, thus, can be said to be representative of the whole population through identifying a suitable sampling frame and the implications for generalizability (Sekaran \& Bougie, 2013; Al-Najjar et al., 2013).

The questionnaire used in this research is divided into three parts. The first part is used to describe the independent variable (Usability), the second part is used to describe the mediator (UIS), and the final part is used to describe the dependent variable (ERP-PIS). The questionnaire uses five-point Likert scale as shown in table (1).

Table 1. Five-point Likert

\begin{tabular}{|c|c|c|c|c|}
\hline \multicolumn{5}{|c|}{ Approval Degree } \\
\hline Very Little & Little & Medium & Big & Very Big \\
\hline (1) & (2) & (3) & (4) & (5) \\
\hline
\end{tabular}

\subsection{Analysis Method}

For the hypotheses testing procedure, the researchers' use SPSS and Structural Equation modeling (SEM) approach with Partial Least Square (PLS) as an analysis method. PLS has been widely used for theory testing and validation. PLS examines the psychometric properties and provides appropriate evidences on whether relationships might or might not exist (Fornell \& Larcker, 1981). In this study, the researchers performed data analysis in accordance with a two-stage methodology (Anderson \& Gerbing, 1988) using Smart PLS 2.0 M3. The first step was to test the content, convergence, and discriminate validity from constructs using the measurement framework, whilst the second step was to test the structural framework and hypotheses.

\subsection{Research Quality Standards Tests}

\subsubsection{Path Loadings}

From suggested framework Factor, analysis allows the researcher to test the hypotheses where a relationship between the observed variable and their underlying latent is constructs existing. As starting point, all items are accepted because the standardized path loadings for all indicators were above 0.55 and thus they are all significant (Falk \& Miller, 1992).All path loadings (factors analysis result) as a suggested framework exist in figure (2). 


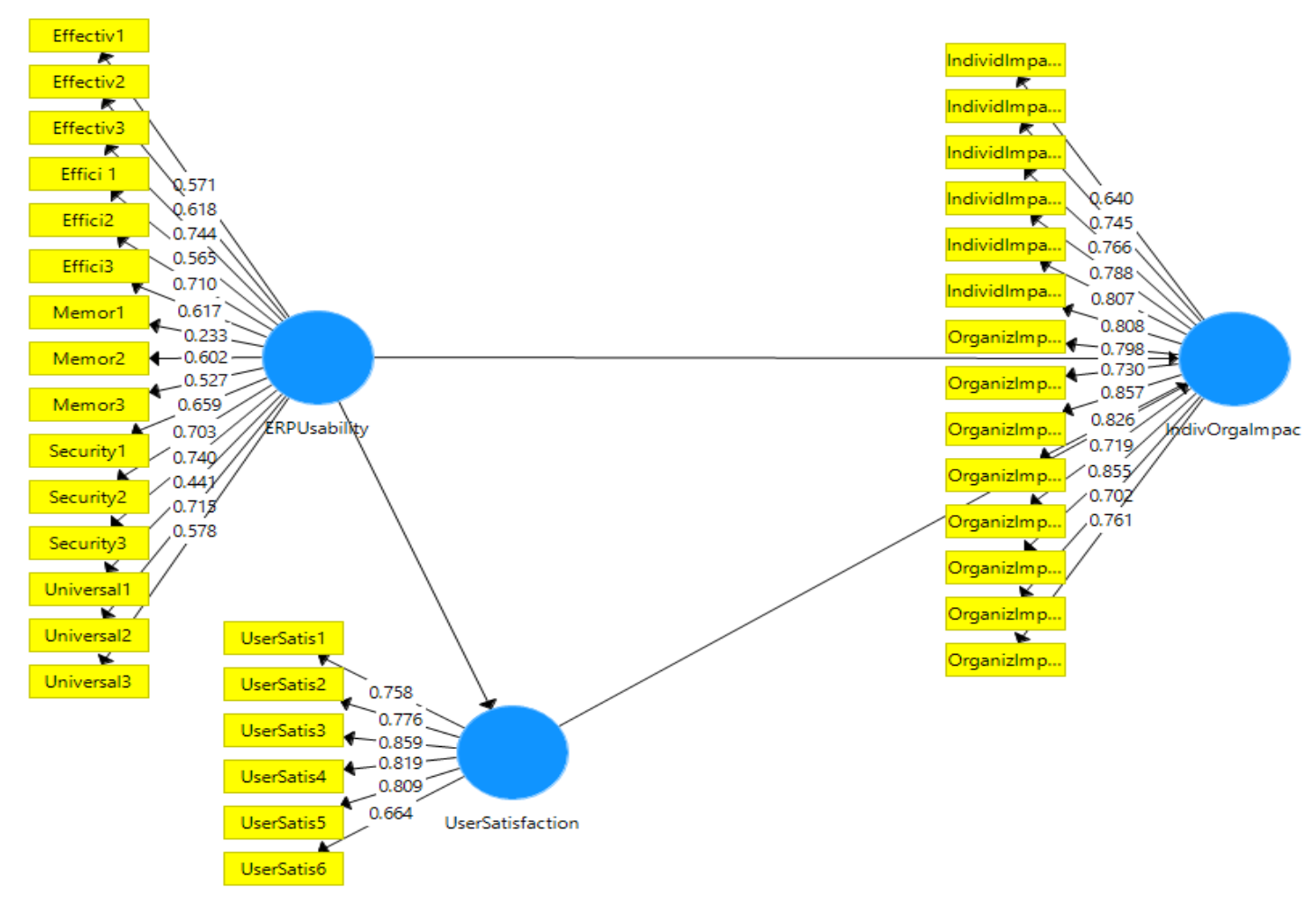

Figure 2. Factor Loading

\subsubsection{Cronbach's Alpha Test}

For reliability of the scale, Cronbach's alpha was used. Hair et al (2006) suggest that the reliability of the scale is generally accepted if the value of Cronbach's alpha for each construct is equal or greater than 0.70 and if 0.60 is good and accepted (Saundres \& Lewis, 2009). See the following figure (3). 


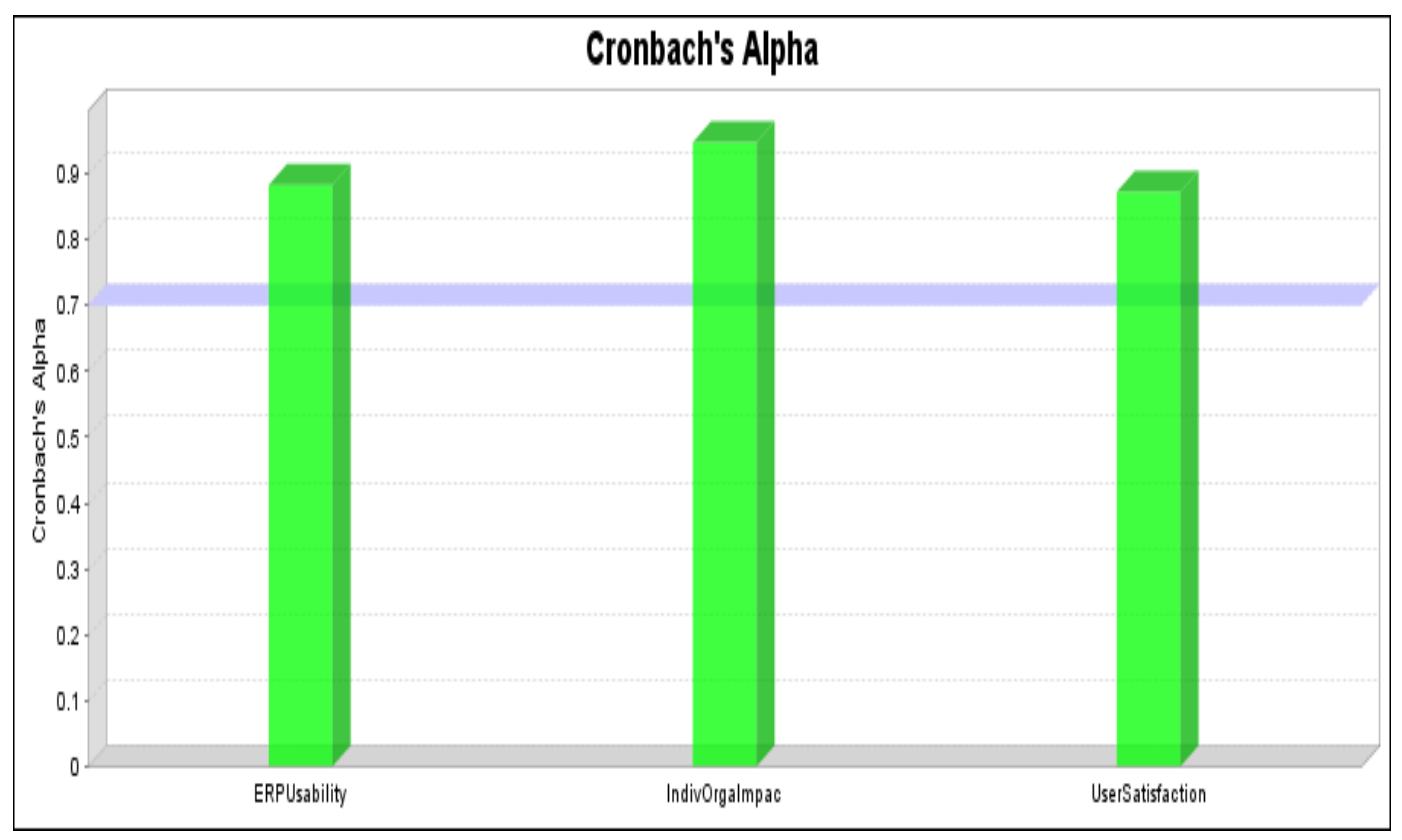

Figure 3. Cronbach's Alpha for all Factors

\subsubsection{Composite Reliability (CR) and Average Variance Extracted (AVE) Tests}

Figure (4) suggests the values of reliability concerning each construct in the questionnaire all these values are considered high and appropriate for the study purposes.

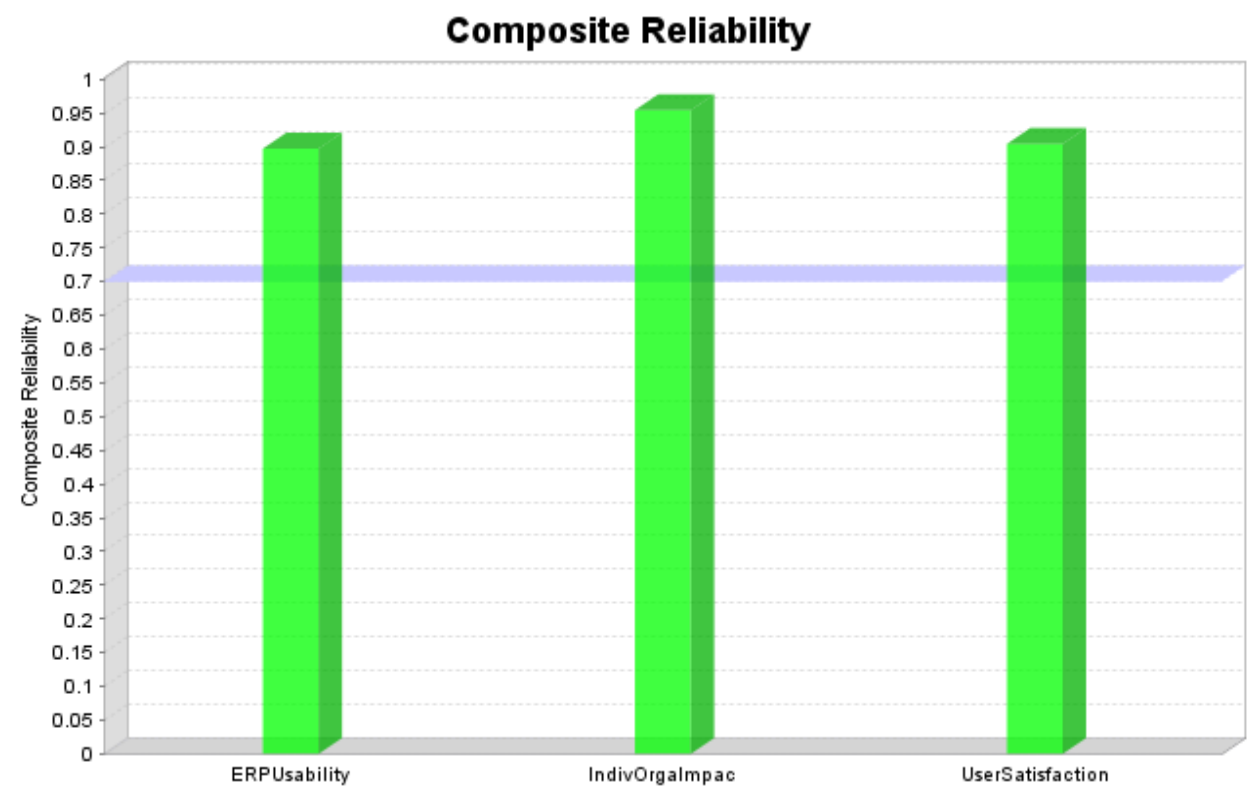

Figure 4. Results using A Composite Reliability (CR) for the Questionnaire Dimensions

A Composite Reliability (CR) conducted to measure convergent validity. Fornell \& Larcker (1981) suggested that the value of CR for each construct must exceed 0.70 . The CR values for the constructs included in the study framework are all above acceptable levels. Moreover, the 


\section{Macrothink}

Journal of Management Research

ISSN 1941-899X 2017, Vol. 9, No. 3

standardized path loadings for all indicators were above 0.55 and thus they are all significant (Falk \& Miller, 1992). As such, content validity, reliability, and convergent validity of the measurement instrument are all satisfactorily met in this study.

\subsection{4. $\mathrm{R}^{2}$ Test}

Table 2 shows evaluation from the prediction-oriented PLS path modeling method's results for the structural model centers on the R2 value.

Table 2. $\mathrm{R}^{2}$

\begin{tabular}{|l|l|}
\hline Endogenous construct & R Square \\
\hline ERP-PIS & 0.632 \\
\hline UIS & 0.683 \\
\hline
\end{tabular}

The $\mathrm{R}^{2}$ value appeared in the table, for the endogenous constructs (individual and organizational impact and user satisfaction) evaluated by prediction-oriented PLS path modeling are: $0.632,0.683$ respectively, exhibits a relatively high R2 value from above 0.50 . Indeed, the high R2 proves the framework's predictive validity (Hair et al, 2012).

\subsubsection{Hypotheses Testing}

The researchers used the bootstrapping procedure and selected 106 cases, to assess the significance of the path coefficients (Hair et al., 2013) see figure (5).

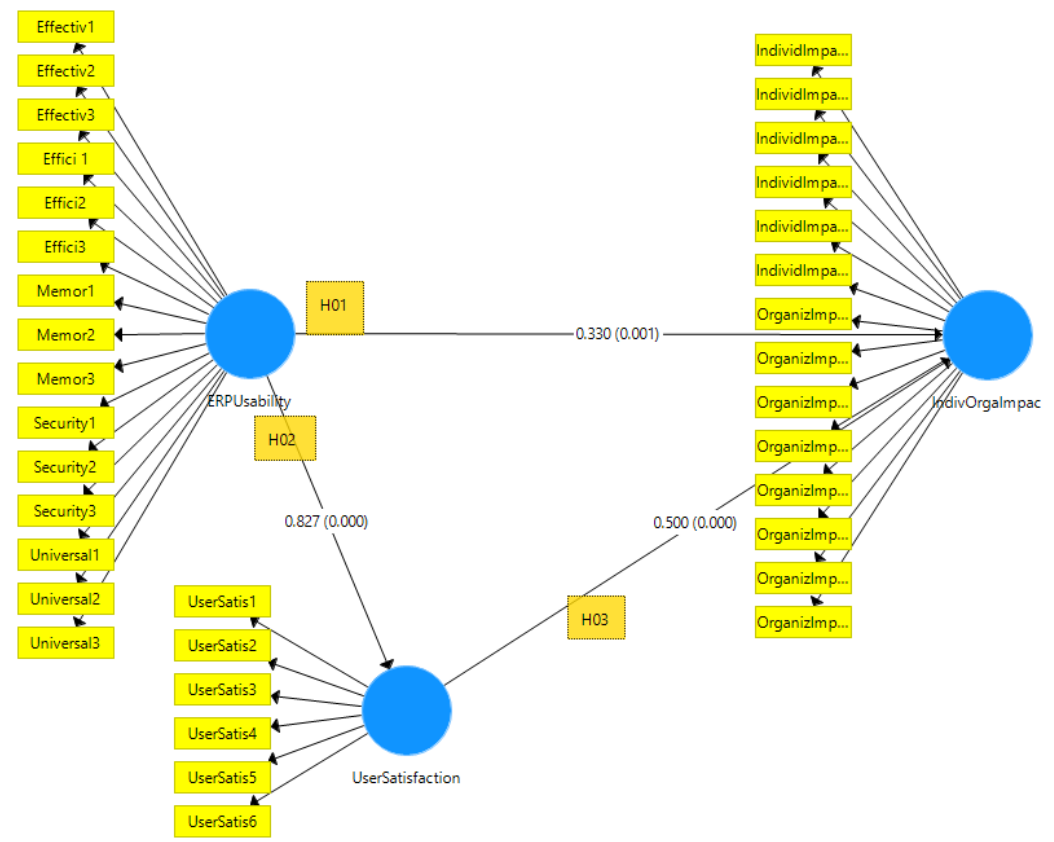

Figure 5. Bootstrapping ( $\beta$, P value) for proposed framework

The researchers have to ask two questions in a mediation analysis; the first question is whether there is a statistically significant mediated path from ERP Software Usability to ERP Implementation Success (individual and organizational impact) via User Satisfaction Based 
on the figure (4) of Bootstrapping ( $\beta$, P value). Recall from MacKinnon \& Fritz (2007) that when a path from independent to dependent includes more than one arrow, the strength of the relationship for this multiple-step path is obtained by multiplying the coefficients for each included path. The researchers summarize all T Statistics, Beta, and determine the significant value. See Table (3).

Table 3. Summarize Results

\begin{tabular}{|l|l|l|l|}
\hline Relation & Beta $(\boldsymbol{\beta})$ & T Statistics & P Values \\
\hline Usability ->ERP-PIS & 0.330 & 3.249 & 0.001 \\
\hline Usability ->UIS & 0.827 & 23.386 & 0.000 \\
\hline UIS > ERP-PIS & 0.500 & 4.566 & 0.000 \\
\hline
\end{tabular}

\section{Findings and Discussions}

$\mathbf{H}_{\mathbf{0}}$ 1: There is no significant impact at level $(P \leq 0.05)$ of Usability on ERP projects implementation success (ERP-PIS).

While T value between ERP Software Usability and ERP-PIS exceeds 1.96 (3.249), and Sigis less than $0.05(0.001)$, and the direct effect $(\beta)$ is 0.33 , thus the research rejects the null hypothesis so:

There is a significant impact at level $(P \leq 0.05)$ of Usability on ERP projects implementation success (ERP-PIS).

This result supports what Kositanurit et al. (2006), Almajali et al. ( 2016) and Nwankpa (2015) proves that usability and user satisfaction enhance general performance for organizations. It also agrees with many other researchers who consider usability as a critical success factor for the whole project. Abu-Shanab \& Saleh, 2014). It also supports Scholtz (2016) findings that interface usability has a significant impact on users' attitudes and intention to use the ERP software.

On the other hand, this research adds the details of impacting ERP-PIS in terms individual and organizational success and the mediation role of UIS.

$\mathbf{H}_{0}$ 2: There is no significant impact at level $(\mathrm{P} \leq .05)$ of Usability on (User Information Satisfaction (UIS).

As T value between ERP Usability and UIS exceeds 1.96 (23.386), and Sig less than 0.05 $(0.000)$, and the direct effect $(\beta)$ is $(0.827)$, thus the result rejects the null sub hypothesis so:

There is a significant impact at level $(P \leq .05)$ of Usability on (User Information Satisfaction (UIS).

Software usability in general is highly considered to acquire user satisfaction as discussed in many researches. Most of the researches study usability's impact of other types of software such as mobile applications, web applications on user satisfaction (Goodman \& Irmak, 2013; Hoehle \& Venkatesh, 2015). Few studies focus on usability on ERP systems specifically.

$\mathbf{H}_{0}$ 3: There is no significant impact at level $(\mathrm{P} \leq .05)$ of User Information Satisfaction (UIS) 
on ERP projects implementation success (ERP-PIS).

While $\mathrm{T}$ value between User Satisfaction and Individual and Organizational Impact exceeds 1.96 (4.566), and Sig is less than 0.05 (0.000), and the direct effect (Beta) is (0.500), thus, the result rejects the null sub hypothesis so:

There is a significant impact at level $(P \leq .05)$ of User Information Satisfaction (UIS) on ERP projects implementation success (ERP-PIS).

Other studies present the value of user satisfaction on ERP success such as Kadir et al. (2015), but to the authors' knowledge it was rarely studied as a mediator.

$\mathbf{H}_{\mathbf{0}} 4$ : There is no significant impact of User Information Satisfaction (UIS) to explain the impact of Usability on ERP projects implementation success (ERP-PIS).

T value between ERP Software Usability and UIS exceeds 1.96 (23.386), and Sig is less than 0.05 (0.000), and the direct effect (Beta) between them is (0.827). Additionally, the $\mathrm{T}$ value between UIS and ERP-PIS exceeds 1.96 (4.566), and Sig is less than $0.05(0.000)$, and the direct effect (Beta) between them is (0.500). As well as, (Indirect Effect) impact of ERP Software Usability on ERP-PIS by mediation from UIS is [(Beta for direct effect $(0.827)$ * (Beta for direct effect $(0.0 .5)]=($ Beta for indirect effect) $(0.413)$. Thus the result rejects the null hypothesis, so

There is a significant impact of User Information Satisfaction (UIS) to explain the impact of Usability on ERP projects implementation success (ERP-PIS).

As this relation was (to the authors' knowledge) rarely studied in literature, the research contributes by providing an explanation for the relation between Usability and ERP-PIS, whereas the UIS mediates and explain this relation

\section{Conclusion}

This study has explored the impact of software usability on ERP projects implementation success (ERP-PIS), considering the mediating role of user information satisfaction. Results of the study have provided details about the nature of the relation between usability and ERP-PIS focusing on managers segment in Jordan. It has also examined the mediation role of user information satisfaction on the relationships between usability of ERP and (ERP-PIS). Based on the study findings, it can be concluded that usability of ERP significantly influences ERP-PIS, specifically in terms of individuals and organizational success. Moreover, the study found that UIS have a significant mediation role on the relationship between usability and ERP-PIS. The research findings will benefit both software organizations and ERP consumer's organizations. It will help to improve software organizations understanding the power of usability to reach implementation success, thus to direct their research on usability improvement.

However, there are some limitations of the study. The first limitation is the use of the same informant for the independent, intermediary, and dependent variables. Even though the researcher tried to reduce data incorrectness by asking the best positioned to answer the 
questionnaire (ERP users), consequently, further research should consider IT managers, business managers, and other stakeholders not only to avoid depending on a single source of information as a way of testing the research model from several perceptions, but also as an attempt to evidence the source of any differences between them. In addition, although the response rate of this study was sufficient for the condition of statistical analysis, the data still unobservable. In other words, even though the research results could be representative, it is reasonable to be watchful in its generalization. Therefore, to increase statistical validity, then further research should consider higher response rates. Moreover, it might be possible that examining the main constructs in this study over a longer period yield more insights. Also, the data and results reported in this paper were based on a single country, Jordan, and in turn are applicable specifically to the Jordanian context. Thus, this raises inquiries regarding the generalizability to other cultures and different contexts. Consequently, further research is needed with regards to several countries in different contexts. Indeed, although this paper investigated several hypotheses and offered empirical support for the acceptance and refusal of some of these hypotheses; more generalizations on the application of the theoretical premises that developed in building the research model will be needed. This is to say, a more generalized research model that compensate the current research limitations by adding further impacting variables to the model and obtain a more representative sample from different sectors will be required. To sum up, further studies in future are needed in order to find out most critical factors of usability. The research's results will also help ERP consumers to make better decisions regarding most appropriate ERP to choose with better usability options in order to raise probability of success.

\section{Acknowledgment}

This research was partially supported by Sky-Tech organization. We are thankful to the employees of SKy-tech organization who provided expertise that greatly assisted the research, although they may not agree with all of the interpretations provided in this paper. In addition, we would like to thank Dr. Issa Otum from World Islamic Science and Education University for his kind support.

\section{References}

Abran, A., Khelifi, A., Suryn, W., \& Seffah, A. (2003). Usability Meanings and Interpretations in ISO Standards. Software Quality Journal, 11(4), 325-338. https://doi.org/10.1023/A:1025869312943

Abu-Shanab, E., Abu-Shehab, R., \& Khairallah, M. (2015). Critical Success Factors for ERP Implementation: The Case of Jordan. The International Arab Journal of e-Technology, 4(1), $1-7$.

Abu-Shanab, E. A., \& Saleh, Z. (2014). Contributions of ERP Systems in Jordan. International Journal of Business Information Systems, 15(2), 244-260. https://doi.org/10.1504/IJBIS.2014.059255

Al Azmi, N., Al-Lozi, M., Al-Zu'bi, Z., Dahiyat, S., \& Masa'deh, R. (2012). Patients Attitudes toward Service Quality and its Impact on their Satisfaction in Physical Therapy in KSA Hospitals. European Journal of Social Sciences, 34(2), 300-314. 
Alkalha, Z., Al-Zu'bi, Z., Al-Dmour, H., \& Alshurideh, M. (2012). Investigating the Effects of Human Resource Policies on Organizational Performance: An Empirical Study on Commercial Banks Operating in Jordan. European Journal of Economics, Finance and Administrative Sciences, 51, 44-64.

Almajali, D. A., Masa'deh, R. E., \& Tarhini, A. (2016). Antecedents of ERP Systems Implementation Success: A Study on Jordanian Healthcare Sector. Journal of Enterprise Information Management, 29(4), 549-565. https://doi.org/10.1108/JEIM-03-2015-0024

Al-Mashari, M., Al-Mudimigh, A., \& Zairi, M. (2003). Enterprise Resource Planning: A Taxonomy of Critical Factors. European Journal of Operational Research, 146(2), 352-364. https://doi.org/10.1016/S0377-2217(02)00554-4

AL-Najjar, F., AL-Najjar, N., \& AL Zuabi, M. (2013). Scientific Research Methods: Applied Perspective, 3rd ed. Jordan, Amman: Dar AlHamed.

Alshurideh, M., Masa'deh, R., \& Alkurdi, B. (2012). The Effect of Customer Satisfaction on Customer Retention in the Jordanian Mobile Market: An Empirical Investigation. European Journal of Economics, Finance and Administrative Sciences, 47, 69-78.

Altamony, H., Alshurideh, M., \& Obeidat, B. (2012). Information Systems for Competitive Advantage: Implementation of an Organizational Strategic Management Process. Proceedings of the 18th IBIMA Conference on Innovation and Sustainable Economic Competitive Advantage: From Regional Development to World Economic, Istanbul, Turkey, 9th-10th May.

Anderson, J. C., \& Gerbing, D. W. (1988). Structural Equation Modeling in Practice: A Review and Recommended Two-Step Approach. Psychological Bulletin, 103(3), 411. https://doi.org/10.1037/0033-2909.103.3.411

Atoum, I., \& Bong, C. H. (2015). Measuring Software Quality in Use: State-of-the-Art and Research Challenges. arXiv preprint arXiv:1503.06934.

Atoum, I., \& Bong, C. H. (2013). A Framework to Predict Software" Quality in Use" from Software Reviews. In DaEng (pp. 429-436).

Au, N., Ngai, E. W., \& Cheng, T. E. (2008). Extending the Understanding of End User Information Systems Satisfaction Formation: An Equitable Needs Fulfillment Model Approach. MIS Quarterly, 43-66.

Aykin, N. (2016). Usability and Internationalization of Information Technology. CRC Press.

Bevan, N., Carter, J., Earthy, J., Geis, T., \& Harker, S. (2016). New ISO Standards for Usability, Usability Reports and Usability Measures. In International Conference on Human-Computer Interaction, pp. 268-278. https://doi.org/10.1007/978-3-319-39510-4_25

Bevan, J. Carter, S. \& Harker, A. (2015). ISO 9241-11 Revised: What have we Learnt about Usability Since 1998?, in: M. Kurosu (Ed.), Human-Computer Interaction: Design and Evaluation, Lecture Notes in Computer Science 9169, Springer, pp. 143-151. https://doi.org/10.1007/978-3-319-20901-2_13 
Bharati, P. \& Chaudhury, A. (2006). Product Customization on the Web: An Empirical Study of Factors Impacting Choiceboard User Satisfaction. Information Resources Management Journal, 19(2), 69-81. https://doi.org/10.4018/irmj.2006040105

Bias, R. G., \& Mayhew, D. J. (2005). Cost-Justifying Usability: An Update for the Internet Age. Elsevier. https://doi.org/10.1016/b978-012095811-5/50022-5

Choi, J. H., \& Moon, J. (2017). Impacts of Human and Spatial Factors on User Satisfaction in Office Environments. Building and Environment, 114, 23-35. https://doi.org/10.1016/j.buildenv.2016.12.003

Davenport, T. (2000). Mission Critical: Realizing the Promise of Enterprise Systems. Harvard Business Press.

DeLone, W. H., \& McLean, E. R. (2016). Information Systems Success Measurement. Foundations and Trends in Information Systems, 2(1), 1-116. https://doi.org/10.1561/2900000005

Dix A., Finlay J., Abowd G. \& Beale R. (2004). Human-Computer Interaction. 3 ed. Prentice-Hall International, 2004.

Doll, W. J., \&Torkzadeh, G. (1988). The Measurement of End-User Computing Satisfaction. MIS Quarterly, 259-274. https://doi.org/10.2307/248851

Dubey, S. K., Gulati, A., \&Rana, A. (2012). Integrated Model for Software Usability. International Journal on Computer Science and Engineering, 4(3), 429.

Falk, R., \& Miller, N. (1992). A Primer for Soft Modeling. Akron, OH: The University of Akron Press.

Finley, B., Boz, E., Kilkki, K., Manner, J., Oulasvirta, A., \& Hämmäinen, H. (2016). Does Network Quality Matter? A Field Study of Mobile User Satisfaction. Pervasive and Mobile Computing. In Press. https://doi.org/10.1016/j.pmcj.2016.08.014

Fornell, C., \& Larcker, D. (1981). Evaluating Structural Equations Models with Unobservable Variables and Measurement Error. Journal of Marketing Research, 18(1), 39-50. https://doi.org/10.2307/3151312

Gable, G. G., Sedera, D., \& Chan, T. (2008). Re-Conceptualizing Information System Success: The IS-Impact Measurement Model. Journal of the Association for Information Systems, 9(7), 377.

Gitman, L., \& McDaniel, C. (2007). The Future of Business: The Essentials. Cengage Learning.

Goodman, J. K., \& Irmak, C. (2013). Having versus Consuming: Failure to Estimate Usage Frequency Makes Consumers Prefers Multifeature Products. Journal of Marketing Research, 50(1), 44-54. https://doi.org/10.1509/jmr.10.0396 
Gupta, D., Ahlawat, A., \& Sagar, K. (2014). A Critical Analysis of a Hierarchy based Usability Model. In Contemporary Computing and Informatics (IC3I), 2014 International Conference on (pp. 255-260). https://doi.org/10.1109/IC3I.2014.7019810

Hair, J., Black, B. B., Anderson, R., \& Tatham, R. (2006). Multivariate Data Analysis. New Jersey: Pearson Prentice Hall.

Hair, J., Hult, G., Ringle, C., \& Sarstedt, M. (2013). A Primer on Partial Least Squares Structural Equation Modeling (PLS-SEM). Sage, Thousand Oaks. https://doi.org/10.1007/s11747-011-0261-6

Hair, J., Sarstedt, M., Ringle, C., \& Mena, J. (2012 ). An Assessment of the Use of Partial Least Squares Structural Equation Modeling in Marketing Research. Journal of the Academy of Marketing Science, 40 (3), 414-433.

Hajir, J., Obeidat, B., \& Al-dalahmeh, M. (2015). The Role of Knowledge Management Infrastructure in Enhancing Innovation at Mobile Telecommunication Companies in Jordan. European Journal of Social Sciences, 50 (3), 313-330.

Halkos, G., \& Bousinakis, D. (2010). The Effect of Stress and Satisfaction on Productivity. International Journal of Productivity and Performance Management, 59(5), 415-431. https://doi.org/10.1108/17410401011052869

Hassenzahl, M., Diefenbach, S., \&AnjaGöritz, A. (2010) Needs, Affect, Interactive Products-Facets of User Experience. Interacting with Computers, 353-362. https://doi.org/10.1016/j.intcom.2010.04.002

Hellman, M. \& Rönkkö, K. (2008). Controlling User Experience through Policing in the Software Development Process. In: Proceedings of I-USED 2008, Pisa.

Hoehle, H., \&Venkatesh, V. (2015). Mobile Application Usability: Conceptualization and Instrument Development. MIS Quarterly, 39(2), 435-472.

Hong, S. G., Hong, S. G., Siau, K., Siau, K., Kim, J. W., \& Kim, J. W. (2016). The Impact of ISP, BPR, and Customization on ERP Performance in Manufacturing SMEs of Korea. Asia Pacific Journal of Innovation and Entrepreneurship, 10(1), 39-54.

Iqbal, M., \& Warraich, N. F. (2016). Usability Evaluation of an Academic Library Website: A Case of the University of the Punjab. Pakistan Journal of Information Management \& Libraries (PJIM\&L), 13.

Ives, B., Olson, M. H., \& Baroudi, J. J. (1983). The Measurement of User Information Satisfaction. Communications of the ACM, 26(10), 785-793. https://doi.org/10.1145/358413.358430

Juristo, N., Moreno, A. M., \& Sanchez-Segura, M. I. (2007). Guidelines for Eliciting Usability Functionalities. IEEE Transactions on Software Engineering, 33(11). https://doi.org/10.1109/TSE.2007.70741 
Kanaan, R., \& Gharaibeh, A. (2013). The Impact of Knowledge Sharing Enablers on Knowledge Sharing Capability: An Empirical Study on Jordanian Telecommunication Firms. European Scientific Journal, 9 (22), 237-258.

Kateb, M., Swies, R., Obeidat, B., \& Maqableh, M. (2015). An Investigation on the Critical Factors of Information System Implementation in Jordanian Information Technology Companies. European Journal of Business and Management, 7(36), 11-28.

Koh, S., Gunasekaran, A. \& Cooper, J. (2009).The Demand for Training and Consultancy Investment in SME-Specific ERP Systems Implementation and Operation. Int. J. Production Economics, 122 (2009), 241-254. https://doi.org/10.1016/j.ijpe.2009.05.017

Kositanurit, B., Ngwenyama, O., \& Osei-Bryson, K. M. (2006). An Exploration of Factors that Impact Individual Performance in an ERP Environment: An Analysis using Multiple Analytical Techniques. European Journal of Information Systems, 15(6), 556-568. https://doi.org/10.1057/palgrave.ejis.3000654

Leon, A. (2014). Enterprise Resource Planning. McGraw-Hill Education.

Loureiro, N., Fernandes, M., Alvarelhão, J., Ferreira, A., Caravau, H., Martins, A. I., \& Queirós, A. (2015). A Web-based Platform for Quality Management of Elderly Care: Usability Evaluation of Ankira. Procedia Computer Science, 64, 666-673. https://doi.org/10.1016/j.procs.2015.08.581

MacKinnon, D. P., Fairchild, A. J., \& Fritz, M. S. (2007). Mediation Analysis. Annu. Rev. Psychol., 58, 593-614. https://doi.org/10.1146/annurev.psych.58.110405.085542

Mahanti, R., \& Evans, J. R. (2012). Critical Success Factors for Implementing Statistical Process Control in the Software Industry. Benchmarking: An International Journal, 19(3), 374-394. https://doi.org/10.1108/14635771211244309

Maqableh, M., \& Karajeh, H. (2014). A Theoretical Perspective on the Relationship between Leadership Development, Knowledge Management Capability, and Firm Performance. Asian Social Science, 10(6), 128.

Maqableh, M., Karajeh, H., \& Masa'deh, R. (2014). Job Scheduling for Cloud Computing Using Neural Networks. Communications and Network, 6(3), 191. https://doi.org/10.4236/cn.2014.63021

Markus, M. L., Axline, S., Petrie, D., \& Tanis, S. C. (2000). Learning from Adopters' Experiences with ERP: Problems Encountered and Success Achieved. Journal of Information Technology, 15(4), 245-265. https://doi.org/10.1080/02683960010008944

Masa'deh, R. (2012). The Impact of Management Information Systems (MIS) on Quality Assurance (QA): A Case Study in Jordan. International Journal of Information, Business, and Management, 93-110.

Masa'deh, R. (2013). The Impact of Information Technology Infrastructure Flexibility on Firm Performance: An Empirical Study of Jordanian Public Shareholding Firms. Jordan Journal of Business Administration, 4(2), 204-224. https://doi.org/10.12816/0002054 
Masa'deh, R., \& Gharaibeh, A. (2015). Knowledge Sharing Capability: A Literature Review. In Fourth Scientific \& Research Conference on New Trends in Business, Management and Social Sciences, Istanbul, Turkey, 19-20 September 2015 (pp. 1-16). https://doi.org/10.2139/ssrn.2696924

Masa'deh, R., \& Shannak, R. (2012). Intermediary Effects of Knowledge Management Strategy and Learning Orientation on Strategic Alignment and Firm Performance. Research Journal of International Studies, 112-128.

Masa'deh, R., Obeidat, B., \& Tarhini, A. (2016). A Jordanian Empirical Study of the Associations among Transformational Leadership, Transactional Leadership, Knowledge Sharing, Job Performance, and Firm Performance: A Structural Equation Modelling Approach. Journal of Management Development, 35(5), 681-705. https://doi.org/10.1108/JMD-09-2015-0134

Masa'deh, R., Shannak, R., Maqableh, M., \& Tarhini, A. (2017). The Impact of Knowledge Management on Job Performance in Higher Education: The Case of the University of Jordan. Journal of Enterprise Information Management, 30 (2), 244-262. https://doi.org/10.1108/JEIM-09-2015-0087

Masa'deh, R., Tayeh, M., Al-Jarrah, I., \& Tarhini, A. (2015). Accounting vs. Market-based Measures of Firm Performance Related to Information Technology Investments. International Review of Social Sciences and Humanities, 129-145.

Nielsen, J., \& Landauer, T. K. (1993). A Mathematical Model of the Finding of Usability Problems. In Proceedings of the INTERACT'93 and CHI'93 conference on Human factors in computing systems (pp. 206-213). ACM. https://doi.org/10.1145/169059.169166

Nielsen, J., \& Loranger, H. (2006). Prioritizing Web Usability. Pearson Education.

Nielsen J, Gilutz S: Return on Investment (ROI) for Usability. Available at: http://www.nngroup. com/reports/usability-return-on-investment-roi/. Accessed 29 Oct 2016

Nwankpa, J. K. (2015). ERP System Usage and Benefit: A Model of Antecedents and Outcomes. Computers in Human Behavior, 45, 335-344. https://doi.org/10.1016/j.chb.2014.12.019

Obeidat, B., El-Rimawi, S., Maqableh, M., \& Al-Jarrah, I. (2013). Evaluating the Profitability of the Islamic Banks in Jordan. European Journal of Economics, Finance and Administrative Sciences, 56, 27-36.

Obeidat, B., Sweis, R., Zyod, D., \& Alshurideh, M. (2012). The Effect of Perceived Service Quality on Customer Loyalty in Internet Service Providers in Jordan. Journal of Management Research, 4 (4), 224-242. https://doi.org/10.5296/jmr.v4i4.2130

Parasuraman, A., Zeithaml, V. A., \& Berry, L. L. (1988). Servqual: A Multiple-Item Scale for Measuring Consumer Perception. Journal of Retailing, 64(1), 12. 
Sadrzadehrafiei, S., Chofreh, A. G., Hosseini, N. K., \& Sulaiman, R. (2013). The Benefits of Enterprise Resource Planning (ERP) System Implementation in Dry Food Packaging Industry. Procedia Technology, 11, 220-226. https://doi.org/10.1016/j.protcy.2013.12.184

Sammon, D., \& Adam, F. (2010). Project Preparedness and the Emergence of Implementation Problems in ERP Projects. Information \& Management, 47(1), 1-8. https://doi.org/10.1016/j.im.2009.09.002

Saunders, M. L., \& Lewis, P. \& Thornhill, A. (2009). Research Methods for Business. (5th Edition), Pearson.

Scholtz, B., Mahmud, I., \& Ramayah, T. (2016). Does Usability Matter? An Analysis of the Impact of Usability on Technology Acceptance in ERP Settings. Interdisciplinary Journal of Information, Knowledge, and Management, 11.

Sedera, D., Gable, G., \& Chan, T. (2004). Measuring Enterprise Systems Success: The Importance of a Multiple Stakeholder Perspective. ECIS 2004 Proceedings, 100.

Seffah, A., Donyaee, M., Kline, R. B., \& Padda, H. K. (2006). Usability Measurement and Metrics: A Consolidated Model. Software Quality Journal, 14(2), 159-178. https://doi.org/10.1007/s11219-006-7600-8

Sekaran, U., \& Bougie, R (2013). Business Research Methods, (6thed.). London, UK: John Wiley \& Sons.

Shackel, B. (1991). Usability-Context, Framework, Definition, Design and Evaluation. Human Factors for Informatics Usability, 21-37.

Shah, S. I. H., Bokhari, R. H., Hassan, S., Shah, M. H., \& Shah, M. A. (2011). Socio-Technical Factors Affecting ERP Implementation Success in Pakistan: An Empirical Study. Australian Journal of Basic and Applied Sciences, 5(3), 742-749.

Sharma, S., Sharma, S., Daniel, E. M., \& Daniel, E. M. (2016). Isomorphic Factors in the Adoption of ERP by Indian Medium-Sized Firms. Journal of Enterprise Information Management, 29(6), 798-821. https://doi.org/10.1108/JEIM-07-2014-0076

Shannak, R., Obeidat, B., \& Almajali, D. (2010). Information Technology Investments: A Literature Review. Proceedings of the 14th IBIMA Conference on Global Business Transformation through Innovation and Knowledge Management: An Academic Perspective, Istanbul-Turkey, 23rd-24th June, pp.1356-1368.

Shen, Y. C., Chen, P. S., \& Wang, C. H. (2016). A study of Enterprise Resource Planning (ERP) System Performance Measurement using the Quantitative Balanced Scorecard

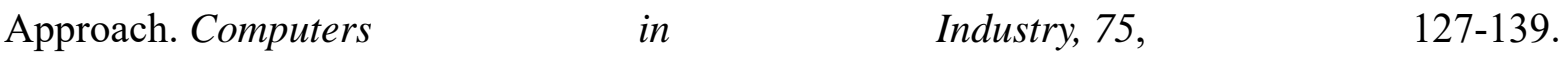
https://doi.org/10.1016/j.compind.2015.05.006

Spreng, R. A., MacKenzie, S. B., \& Olshavsky, R. W. (1996). A Reexamination of the Determinants of Consumer Satisfaction. Journal of Marketing, 60(3), 15-32. https://doi.org/10.2307/1251839 
Statista.

(2017)

https://www.statista.com/statistics/558784/worldwide-erp-market-share-distribution-by-vend or/ Accessed on 15/3/2017.

Sugianto, L. F., \&Tojib, D. R. (2015). Modelling User Satisfaction with an Employee Portal. International Journal of Business and Information, 1(2).

Sykes, T. A. (2015). Support Structures and Their Impacts on Employee Outcomes: A Longitudinal Field Study of an Enterprise System Implementation. MIS Quarterly, 39(2), 437-495.

Tarhini, A., Ammar, H., \&Tarhini, T. (2015). Analysis of the Critical Success Factors for Enterprise Resource Planning Implementation from Stakeholders' Perspective: A Systematic Review. International Business Research, 8(4), 25-40. https://doi.org/10.5539/ibr.v8n4p25

Tasevska, F., Damij, T., \& Damij, N. (2014). Project Planning Practices based on Enterprise Resource Planning Systems in Small and Medium Enterprises-A Case Study from the Republic of Macedonia. International Journal of Project Management, 32(3), 529-539. https://doi.org/10.1016/j.ijproman.2013.08.001

Tretten, P., \& Karim, R. (2014). Enhancing the Usability of Maintenance Data Management Systems. Journal of Quality in Maintenance Engineering, 20(3), 290-303. https://doi.org/10.1108/JQME-05-2014-0032

Umble, E. J., Haft, R. R., \& Umble, M. M. (2003). Enterprise Resource Planning: Implementation Procedures and Critical Success Factors. European Journal of Operational Research, 146(2), 241-257. https://doi.org/10.1016/S0377-2217(02)00547-7

Veiga, J. F., Keupp, M. M., Floyd, S. W., \& Kellermanns, F. W. (2014).The Longitudinal Impact of Enterprise System Users' Pre-Adoption Expectations and Organizational Support on Post-Adoption Proficient Usage. European Journal of Information Systems, 23(6), 691-707. https://doi.org/10.1057/ejis.2013.15

Vratskikh, I., Al-Lozi, M., \& Maqableh, M. (2016). The Impact of Emotional Intelligence on Job Performance via the Mediating Role of Job Satisfaction. International Journal of Business and Management, 69-91. https://doi.org/10.5539/ijbm.v11n2p69

Wang, G., \& Song, J. (2017). The Relation of Perceived Benefits and Organizational Supports to User Satisfaction with Building Information Model (BIM). Computers in Human Behavior, 68, 493-500. https://doi.org/10.1016/j.chb.2016.12.002

Wang, Y., Greasley, A., \& Albores, P. (2016). Do Manufacturing Firms Need Informality in ERP Post-Implementation? A Study of Chinese Manufacturing Sites. Journal of Manufacturing Technology Management, 27(1), 100-123. https://doi.org/10.1108/JMTM-09-2015-0077

Wittstruck, D., \& Teuteberg, F. (2012).Understanding the Success Factors of Sustainable Supply Chain Management: Empirical Evidence from the Electrics and Electronics Industry. Corporate Social Responsibility and Environmental Management, 19(3), 141-158. https://doi.org/10.1002/csr.261 
Wu, L., Ong, C. \& Hsu, Y. (2008). Active ERP Implementation Management: A Real Options Perspective. The Journal of Systems and Software, 81, 1039-1050. https://doi.org/10.1016/j.jss.2007.10.004

Yassien, E. (2015). A Big Picture of Dynamic Capabilities. Journal of Management Research, 7(5), 63-78. https://doi.org/10.5296/jmr.v7i5.8007

Yassien, E., Aljawarneh, S., \& Ghaleb, B. (2016). A New Dynamic Trickle Algorithm for Low Power and Lossy Networks. Engineering \& MIS (ICEMIS), International Conference on IEEE. https://doi.org/10.1109/icemis.2016.7745314

Zainal, H. B., \& Sa'don, N. F. B. (2013). Web OPAC End User Satisfaction from Library Science and Information System Perspectives. Research and Innovation in Information Systems (ICRIIS), 487-492. https://doi.org/10.1109/icriis.2013.6716758 